Vegetatio 77: 193-200, 1988

\title{
Species diversity of mainland- and island forests in the Pacific area
} Syuzo Itow

Plant Ecology Laboratory, Faculty of Liberal Arts, Nagasaki University, Nagasaki 852, Japan Accepted 25.5.1988

Keywords: Bonin, Galapagos, Isolation, Micronesia, Ryukyu, Species richness, Warmth index

\begin{abstract}
Alpha diversity, or species richness, of East Asian mainland evergreen broadleaved forests, expressed by indices of Fisher's alpha $(\alpha)$ and $\mathrm{S}(100)$, a new index showing species number in a 100-individual sample, is significantly correlated with the climatic favorableness, expressed by Kira's warmth index. On the contrary, diversity values of insular forests studied on Kynshu satellites of Japan, the Bonins, the Eastern Carolines of Micronesia, and the Galapagos in the eastern Pacific, are below those expected from the climate of respective oceanic islands. Species-individual curves, comparing mainland- and insular communities, also support clearly the above conclusion of species poverty in the insular communities studied.
\end{abstract}

Abbreviations: $\mathrm{WI}=$ Kira's (1977) warmth index.

Nomenclature: I. L. Wiggins \& D. M. Porter 1971. Flora of the Gahtpagos Islands. Palo Alto; R. Kanehira 1972.Flora Micronesica. Tokyo.

\section{Introduction}

Biotic saturation of oceanic islands is one of the both old and modern concerns of biologists studying insular ecosystems. In island studies we have to distinguish the species richness of a community from the floristic magnitude of an island. A plant community usually consists of species unique to the community and of species shared with other communities. The vegetation of an island comprises various plant community types and the flora of the island will include both sets of community -specific and common plant species.

The concept of alpha diversity denotes the species richness within a community, whereas gamma diversity means the richness in a region or on an island (Whittaker 1977). The present paper only deals with the alpha diversity of mainland- and insular communities.

Alpha diversity is a structural feature of the plant community, just like stratification and physiognomy. It depends on various factors such as climatic conditions, continentality, soil moisture and fertility, topography, and disturbance (Whittaker 1972, 1977; Glenn-Lewin 1977; Peet 1978; 
Peet et al. 1983). From the dynamic point of view alpha diversity also depends on the successional status of the community, and it generally increases towards the equilibrium level at the climax stage (Auclair \& Goff 1971; Peet et al. 1983). In my study (Itow 1985) of mainland communities of East Asian warm-temperate and subtropical climates, the alpha diversity of evergreen broadleaved forests is correlated with climatic favourableness, but that of insular communities is not.

The present study will continue along these lines while including data from tropical mainland and insular communities (Itow 1986) and of nine equatorial South American communities. The communities studied are all climatic climaxes, considered to represent maximum alpha diversity at equilibrium level, or nearly so.

\section{Study areas and their climate}

Mainland and insular communities will be compared between and within climatic regions. Three pairs of mainland areas and oceanic islands in different climatic regions will be compared. The communities actually studied were all natural- and climax forests, being free of disturbance by man and alien plants.

\section{Warm-temperate region}

The Japanese Archipelago is an island chain, which was connected to the Asian continent in the glacial period, some 20000 years ago. The northern temperate region of the archipelago supports a summergreen forest, while an evergreen broadleaved forest is found in the southern warmer part. The present paper deals only with the evergreen broadleaved climax forests found in Kyushu, southwestern Japan $\left(31^{\circ} \mathrm{N}-34^{\circ} \mathrm{N}\right)$. The forests are dominated by evergreen Castanopsis and Quercus (Cyclobalanopsis) species (Miyawaki \& Sasaki 1985).

Three satellite islands of Kyushu are used as counterpart of the Kyushu main island. They are Meshima of the Danjo Islands, Biryo-jima of the Goto Islands and Okinoshima. The Fagaceae species are absent on all three islands. This may be because the diaspores (acorns) did not cross the sea when the species were expanding their distribution range towards the north in the period of the rise of the sea level during the post-glacial age. Itow (1984) gives a detailed description of Kyushu satellite communities and the measurement of their diversity.

\section{Subtropical region}

The Ryukyu Islands are the southernmost part of the Japanese Archipelago $\left(24^{\circ} \mathrm{N}-27^{\circ} \mathrm{N}\right)$. They are continental islands that were connected with the Asian continent in the early Pleistocene. The climax forests are also dominated by evergreen Castanopsis or Quercus (Cyclobalanopsis) species (Miyawaki \& Sasaki 1985). The islands Ishigaki, Iriomote and Yonaguni at $24^{\circ} 30^{\prime} \mathrm{N}$ were included with data from Itow et ai. (1984). 
The Bonin (Ogasawara) Islands are oceanic islands, located about $1000 \mathrm{~km}$ east of the Ryukyus and $1000 \mathrm{~km}$ south of Tokyo, between $26^{\circ} 30^{\prime} \mathrm{N}$ and $27^{\circ} 30^{\prime} \mathrm{N}$. The geological structure of the islands is complicated, and their origin is probably late Pliocene. Apparently the islands have never been connected to any continent or large land mass. Acornbearing trees are absent on the islands. Canopy species are mainly Lauraceae, Elaeocarpaceae, Myrsinaceae and Aquifoliaceae with seeds carried by birds, either internally or externally (Ono \& Sugawara 1981; Shimizu 1983; Okutomi et al. 1985). The diversity studies were made on the two islands Chichi-jima and Haha-jima (Itow et al. 1984).

\section{Tropical region}

The present study uses data on Thailand forests by Ogawa et ai. (1965: loc. cit. Tables 6 and 7) as continental communities. The forest is tropical rain forest, and very rich in species (Itow \& Miyata 1977; Itow 1986).

The Eastern Carolines of Micronesia are oceanic islands of volcanic origin, of which Ponape and Kosrae were visited. The inland forest on both islands is well preserved. The common canopy species are Campnosperma brevipetiolata (Anacardiaceae) on Ponape and Horsfieldia nunu (Myristicaceae) on Kosrae (Itow 1986; Nakano et al. 1986). Field work was conducted in 1985 for tree populations $(\mathrm{dbh} \geqq 10 \mathrm{~cm})$.

\section{Equatorial South America}

The Galapagos Islands are the main target of the present study. For comparison Amazonian equatorial tropical rain forests between $77^{\circ} \mathrm{W}$ and $78^{\circ} \mathrm{W}$ (Grubb et al. 1963: loc. cit. Table 6) were included. Two communities were lowland and one montane (Table 1).

The Galapagos Islands are located on the equator in the eastern Pacific, about $1000 \mathrm{~km}$ west of the South American coast. The islands are of volcanic origin, and at least 3 million yr old (Bailey 1976). Isla Santa Cruz is centrally located in the archipelago, between $0^{\circ} 30^{\prime} \mathrm{S}$ and $0^{\circ} 50^{\prime} \mathrm{S}$. The island supports four vegetation zones: Coastal Arid, Transition, Moist, and Highland Zones (Itow 1971; Wiggins \& Porter 1971; Hamann 1979). Although the archipelago as a whole has a dry climate, the Moist Zone receives more than $1500 \mathrm{~mm}$ rainfall (Hamann 1979) and supports a dense forest of Scalesia pedunculata (Compositae). This tree is $15 \mathrm{~m}$ high and $20 \mathrm{~cm}$ across at maximum growth (See also Lawesson 1988). The field work was conducted in 1978 and 1981 at three stands of the Scalesia forest (Table 2), at one in the Transition Zone and two in the Arid Zone (Table 3). 
Table 1. Tree population sizes ( $>20 \mathrm{ft}$ high) adapted to a geometric series for three equatorial Amazonian forests of Ecuador reported by Grubb et al. (1963). Only samples with more than 50 trees are used.

\begin{tabular}{|c|c|c|c|c|}
\hline \multirow{2}{*}{\multicolumn{2}{|c|}{ Locality }} & \multicolumn{2}{|l|}{ Lowland } & \multirow{2}{*}{$\begin{array}{l}\text { Montane } \\
\text { Borja }\end{array}$} \\
\hline & & $\begin{array}{l}\text { Armenia } \\
\text { Vieja }\end{array}$ & Araki & \\
\hline \multicolumn{2}{|c|}{ No. of individuals } & 101 & 52 & 52 \\
\hline \multicolumn{2}{|c|}{ No. of species } & 42 & 30 & 27 \\
\hline \multicolumn{2}{|c|}{ Species occurring once } & 24 & 22 & 18 \\
\hline \multirow[t]{18}{*}{ Species } & 1 & 8 & 5 & 6 \\
\hline & 2 & 7 & 5 & 5 \\
\hline & 3 & 7 & 4 & 4 \\
\hline & 4 & 6 & 4 & 4 \\
\hline & 5 & 6 & 3 & 4 \\
\hline & 6 & 5 & 3 & 3 \\
\hline & 7 & 5 & 3 & 3 \\
\hline & 8 & 4 & 3 & 3 \\
\hline & 9 & 4 & & 3 \\
\hline & 10 & 4 & & \\
\hline & 11 & 3 & & \\
\hline & 12 & 3 & & \\
\hline & 13 & 3 & & \\
\hline & 14 & 3 & & \\
\hline & 15 & 3 & & \\
\hline & 16 & 2 & & \\
\hline & 17 & 2 & & \\
\hline & 18 & 2 & & \\
\hline
\end{tabular}

Table 2. Species and number of trees $(\mathrm{dbh} \geqq 5 \mathrm{~cm})$ in three stands of Scalesia pedunculata forest in the Moist Zone on Isla Santa Cruz, Galapagos Islands.

\begin{tabular}{lrrr}
\hline Stand & G-1 & G-2 & G-3 \\
Altitude (m) & 590 & 640 & 530 \\
\hline Scalesia pedunculata & 82 & 98 & 85 \\
Psidium galapageium & 14 & - & 8 \\
Zanthoxylum fagara & 2 & 1 & 7 \\
Pisonia floribunda & 5 & - & - \\
Chiococca alba & 1 & 2 & - \\
Cordia anderssonii & - & 3 & - \\
Tournefortia rufo-sericea & - & - & 3 \\
Acnistus ellipticus & - & - & 2 \\
& & & \\
No. of species & 5 & 4 & 5 \\
No. of individuals & 104 & 104 & 105 \\
\hline
\end{tabular}


Table3. Species and number of trees $(\mathrm{dbh} \geqq 5 \mathrm{~cm})$ in three stands of Bursera graveolens forest in the Arid and Transition Zones on Isla Santa Cruz, Galapagos Islands.

\begin{tabular}{lrrr}
\hline Stand & G-4 & G-5 & G-6 \\
Alt. (m)| & 350 & 210 & 150 \\
\hline Bursera graveolens & 50 & 65 & 53 \\
Piscidia carthagensis & 18 & 7 & 18 \\
Zanthoxylum fagara & 13 & 8 & 1 \\
Waltheria ovata & 1 & 2 & 3 \\
Chiococca alba & 2 & 1 & 5 \\
Tournefortia pubesens & 5 & 2 & 2 \\
Castela galapagensis & - & 6 & 3 \\
Croton scouleri & - & 2 & 7 \\
Scalesia crockerii & - & 4 & 1 \\
Acacia macracantha & - & 1 & 6 \\
Pisonia floribunda & 14 & - & - \\
Scutia pauciflora & - & 1 & 4 \\
Erythrina velutina & 1 & - & - \\
Tournefortia psylostachya & - & 1 & - \\
Vallesia glabra & - & 1 & - \\
Opuntia echios & - & 1 & - \\
& & & \\
No. of species & 8 & 14 & 11 \\
No. of individuals & 104 & 102 & 103 \\
\hline & & &
\end{tabular}

\section{Climate of the study sites}

The study sites, except the Galapagos forests, are all located in humid climates, with a rainfall between $1500 \mathrm{~mm}$ and $4500 \mathrm{~mm}$, supporting evergreen broadleaved forest, or rain forest.

The mean annual temperatures range from $14{ }^{\circ} \mathrm{C}$ in the warm-temperate climate to $27^{\circ} \mathrm{C}$ in the tropical. The thermal favourableness is expressed by Kira's (1977) Warmth Index (hereafter abbreviated as WI). This index represents a ratio of the total amount of heat available for plant life, and is given as

$$
\mathrm{WI}=\Sigma(\mathrm{t}-5) \text {, }
$$

where $\mathrm{t}$ is the mean monthly temperature exceeding $5^{\circ} \mathrm{C}$. WI values from $85-180$ relate to warmtemperate climates, WI $=180-240$ to subtropical, and WI $>240$ to tropical ones (Kira 1977). The WI value for each of the forest stands studied was estimated using a lapse rate of $0.57^{\circ} \mathrm{C} / 100 \mathrm{~m}$ altitude from the temperature records made at the nearby weather stations. The WI values for the three Amazonian communities could not be calculated. 


\section{Field methods, diversity indices and $S-N$ curves}

The field methods I adopted are the quadrat method, the quarter method (Cottam \& Curtis 1956) and minimum sampling program (Itow 1984, 1985). The trees sampled are $\geqq 3 \mathrm{~cm}$ dbh unless otherwise noted. With the quadrat method, five or ten $10 \mathrm{~m} \times 10 \mathrm{~m}$ quadrats were laid out and more than 200 trees were sampled. With the quarter method and the minimum sampling program, a little more than 100 trees were sampled. The minimum program is a method of diversity measurement applicable in the field when time and assistance are limited. Preferably the sampling includes more than 150 individuals and the measurement record of their $\mathrm{dbh}$.

Diversity indices adopted in the present study are Fisher's alpha ( $\alpha)$ (Williams 1947),

$$
S=\alpha \log \mathrm{e}(1+N / \alpha)
$$

and Itow's (1984) S(100) calculated by Hurlbert's (1971) equation, as given below,

$$
S_{(100)}=\Sigma\left[1-\left(\begin{array}{c}
N-N_{i} \\
100
\end{array}\right) /\left(\begin{array}{c}
N \\
100
\end{array}\right)\right]
$$

where $\mathrm{S}$ is the number of species, $\mathrm{N}$ is the number of individuals, and $N i$ is the number of individuals of the $\mathrm{i}$-th species found in a community. The $\mathrm{S}(100)$ index means the estimated number of species in a sample of 100 individuals, but it does not aim to find the collective number of species in the community at large. $\mathrm{S}(100)$ is an index of species diversity, which is useful and easy to understand (Itow 1984, 1985, 1986; Itow et al. 1984).

Since Hurlbert's (1971) equation gives the number of species for $n$ individuals in the community, species-individuals (S-N) curves for the community can be drawn. The curve is another way to express diversity characteristics (Itow 1984, 1985). It is applicable to any data, even if the sample area is not given. The rate of increase from $S_{(50)}$ to $S_{(100)}$, which is called $b$ in the present paper,

$$
b=\frac{S_{(100)}-S_{(50)}}{\log 100-\log 50}
$$

is also useful as an index of species diversity (Itow 1984, 1985, 1986). For the stands from which fewer than 100 trees were sampled, b was calculated with $\mathrm{S}(50)$ and $\mathrm{S}(\mathrm{N})$ or with $\mathrm{S}(40)$ and $\mathrm{S}(50)$, and in this case S000) was obtained by projection using $b$.

The indices of species diversity used in the present study express the characteristics of community structure as follows. Fisher's $\alpha$ gives an estimation of the number of species represented by a single individual in the community in which the population distribution fits the logarithmic series (Williams 1947). S(100) denotes the species richness found in a sample of 100 individuals. The parameter $\mathrm{b}$ represents the population evenness in the community. The S-N curve is a graphic presentation of the species richness and the population evenness. 
In addition to the above-mentioned indices, Shannon's H' and the complement of Simpson's index, d', were also calculated for comparison with other literature (See Itow 1984, 1985).

For the Amazonian communities, only the number of individuals ( $>20 \mathrm{ft} \mathrm{high}$ ) and the number of species occurring once were given. Here the number of individuals for the species occurring more than once were estimated, on the basis of a geometric series (Table 1). The values of diversity indices for the three Amazonian communities were thus calculated based on that estimated distribution of populations (First 3 stands in Table 4). The estimated numbers of species were used only in drawing the $S-N$ curve.

Table 4. Diversity measurements of tree populations in natural forests in mainland Ecuador (first three stands calculated from Grubb et al. 1963) and on the Galapagos Islands (G-I to G-6).

\begin{tabular}{lccccccccc}
\hline Stand & $\begin{array}{l}\text { Armenia } \\
\text { Vieja }\end{array}$ & Araki & Borja & G-1 & G-2 & G-3 & G-4 & G-5 & G-6 \\
\hline Alt. (m) & 300 & 300 & 1710 & 590 & 640 & 530 & 350 & 210 & 150 \\
WI & & & & 200 & 208 & 205 & 215 & 221 & 222 \\
& & & & & & & & & \\
$S$ & 42 & 30 & 27 & 5 & 4 & 5 & 8 & 14 & 11 \\
$S_{1}^{{ }^{*}}$ & 24 & 22 & 18 & 1 & 1 & 0 & 2 & 6 & 2 \\
$N$ & 101 & 52 & 52 & 104 & 104 & 105 & 104 & 102 & 103 \\
& & & & & & & & & \\
$H^{\prime}$ & 4.96 & 4.58 & 4.41 & 1.04 & 0.40 & 1.05 & 2.16 & 2.12 & 2.37 \\
$d^{\prime}$ & 0.96 & 0.95 & 0.94 & 0.36 & 0.11 & 0.33 & 0.70 & 0.58 & 0.69 \\
$\alpha$ & 27.4 & 29.6 & 22.6 & 1.1 & 0.83 & 1.1 & 2.0 & 4.4 & 3.1 \\
$S_{(50)}$ & 28.2 & 29.2 & 26.3 & 4.2 & 3.1 & 4.6 & 6.7 & 10.1 & 9.3 \\
$S_{(100)}$ & 41.8 & 42.6 & 37.2 & 5.0 & 4.0 & 5.0 & 7.9 & 13.9 & 10.9 \\
$b$ & 45.02 & 44.37 & 36.12 & 2.60 & 2.93 & 1.41 & 4.19 & 12.63 & 5.38 \\
\hline
\end{tabular}

* Number of species occurring once.

\section{Results and discussion}

Figures 1 and 2 give the regression lines for Fisher's $\alpha$ on WI and of S(100 ) on WI respectively. The regression equations are $\log \mathrm{Y}=0.2675+0.00424 \mathrm{X}$ for the a relation and $\log \mathrm{Y}=0.9468+$ $0.00249 \mathrm{X}$ for the $\mathrm{S}(100)$ relation, where $\mathrm{Y}$ is $\alpha$ or $\mathrm{S}(100)$, respectively, and $\mathrm{X}$ is the WI value. Both regressions are positively significant $(\mathrm{p}<0.05)$. Thus, alpha diversity of mainland climax communities of humid climates is predictable from the WI index reflecting the thermal favourableness for plant life. Glenn- Lewin (1977) recognized a similar relation between diversity and elevation and latitude in North American temperate forests.

To compare the insular communities with the mainland ones, I plotted the index values of insular communities of Kyushu satellites (Itow 1984), the Bonins (Itow et al. 1984), Micronesia (Itow 1986) and the Galapagos' communities (Stands G-1 to G-6 in Table 4) in the same graphs (Figs 1 and 2). I used all these Galapagos communities as given in Tables 2 and 3, in spite of their wide range of 
climatic conditions from dry to humid. It is clear that insular communities under all climatic conditions included have far lower diversities than comparable mainland communities and that no diversity trends can be seen within the set of insular communities (Figs 1 and 2). Clearly, alpha diversity of insular communities depends largely on factors other than the climate. One important factor is isolation.

Table 5 presents a summary of all diversity values. It shows once more that the insular communities are poor in species as compared with the mainland ones. The significant correlation between diversity and climatic favourableness in mainland communities can be interpreted so that the mainland communities are more or less saturated with plant species. The fact that the mainland communities studied had not been invaded by alien plants supports this interpretation. In contrast, the insular communities are not saturated up to and far below the richness level expected from the climatic favourableness. The $S-N$ curve is a graphic presentation of alpha diversity (Itow 1984, 1985, 1986; Itow et al. 1984). In Fig. 3 the curves of mainland and insular communities are compared. The level of $\mathrm{S}(100)$ shows community species richness and the slope of the curve (b in the present paper) shows the evenness in population size within the community. Apparently, the curves for the mainland communities are much steeper than those for the insular ones (Fig. 3).

The results of the present study do not elucidate possible causes for species poverty of insular communities. Here a special study is needed of the islands' geology and history and of the ecological consequences of species poverty, such as habitat expansion of plant species, invasion by aliens, and vulnerability of island ecosystems as a whole. 


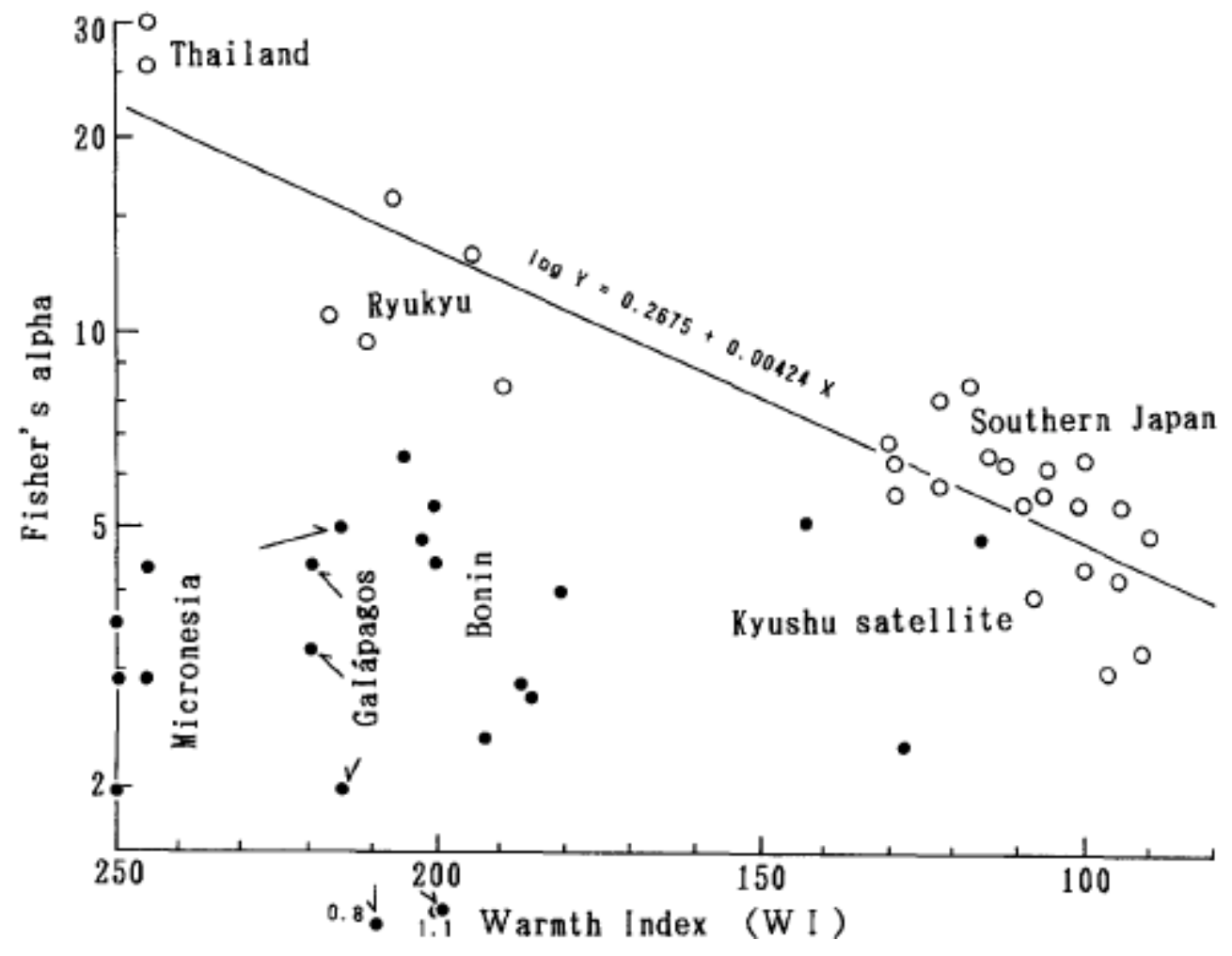

Fig. 1. Alpha-WI correlation in mainland communities (open circles) of humid climate in East Asia. Closed circles show insular communities. Note their positions plotted far below the regression line of the mainland communities.

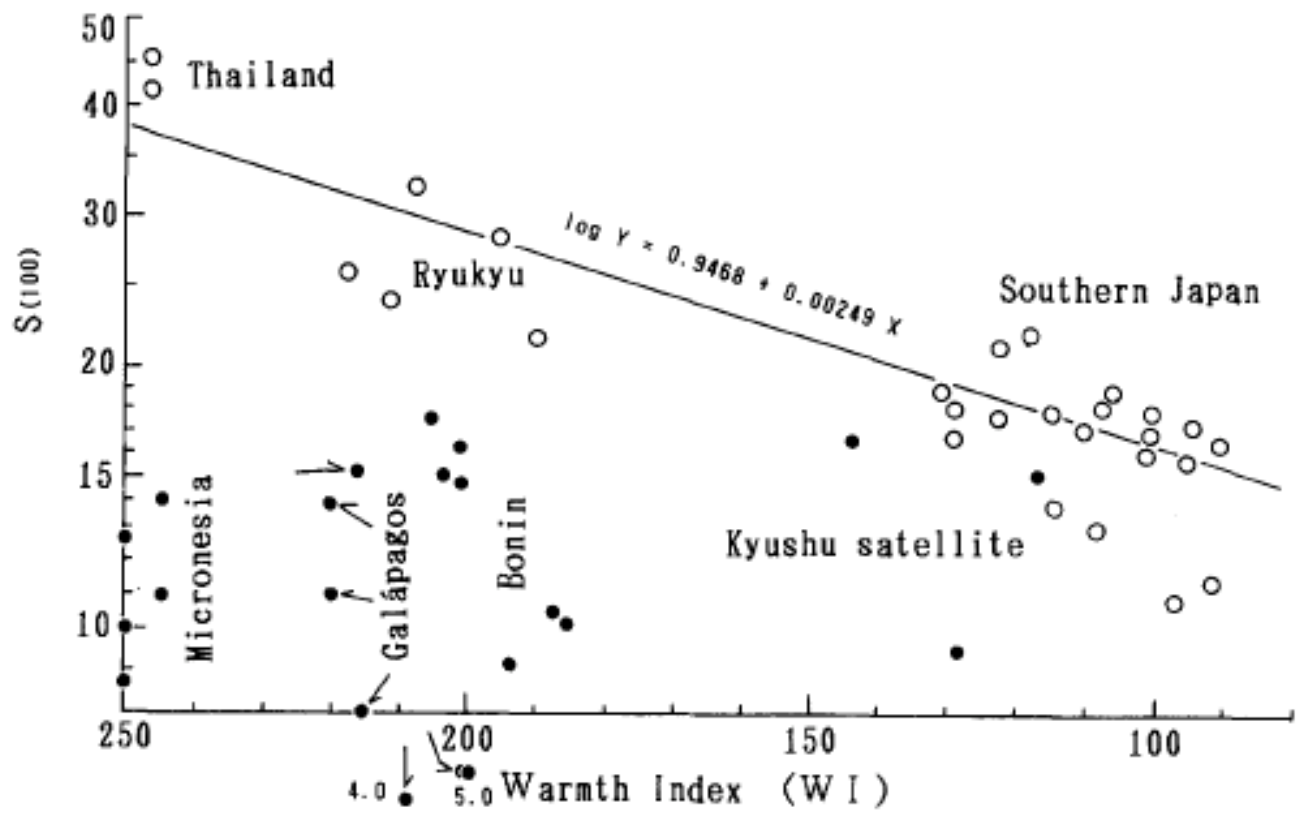

Fig. 2. S(100)-WI correlation in mainland communities (open circles). Closed circles show the insular communities. 
Table 5. Comparison of diversity values as averages and ranges between natural forest communities of mainlands and satellite islands in the warm-temperate, subtropical and tropical climates of East Asia and pacific South America.

\begin{tabular}{|c|c|c|c|c|}
\hline & \multicolumn{2}{|c|}{ Mainlands } & \multicolumn{2}{|c|}{ Satellites } \\
\hline & \multicolumn{2}{|r|}{ SW Japan } & \multicolumn{2}{|c|}{ Kyushu satellites } \\
\hline WI & \multicolumn{2}{|r|}{$90-130$} & \multicolumn{2}{|c|}{$116-143$} \\
\hline$H^{\prime}$ & 3.34 & $(2.35-3.94)$ & 3.29 & $(3.27-3.30)$ \\
\hline$d^{\prime}$ & 0.85 & $(0.71-0.92)$ & 0.85 & $(0.84-0.85)$ \\
\hline$\alpha$ & 5.7 & $(3.0-8.4)$ & 5.0 & $(4.9-5.1)$ \\
\hline$S_{(100)}$ & 16.9 & $(10.7-21.6)$ & 15.8 & $(15.2-16.4)$ \\
\hline \multirow[t]{3}{*}{$b$} & 11.9 & $(5.8-17.8)$ & 7.3 & $(3.3-9.3)$ \\
\hline & \multicolumn{4}{|c|}{ Subtropical } \\
\hline & \multicolumn{2}{|r|}{ Ryukyu } & \multicolumn{2}{|r|}{ Bonins } \\
\hline WI & \multicolumn{2}{|r|}{$190-217$} & \multicolumn{2}{|r|}{$182-205$} \\
\hline$H^{\prime}$ & 3.95 & $(3.51-4.23)$ & 2.58 & $(1.63-3.43)$ \\
\hline$d^{\prime}$ & 0.89 & $(0.80-0.94)$ & 0.71 & $(0.49-0.89)$ \\
\hline$\alpha$ & 11.6 & $(8.1-16.4)$ & 4.15 & $(2.39-6.45)$ \\
\hline$S_{(100)}$ & 26.0 & $(21.0-32.2)$ & 13.2 & $(9.0-17.3)$ \\
\hline \multirow[t]{3}{*}{$b^{(10)}$} & 22.5 & $(16.1-34.7)$ & 8.7 & $(5.7-11.8)$ \\
\hline & \multicolumn{4}{|c|}{ Tropical } \\
\hline & \multicolumn{2}{|c|}{ Thailand } & \multicolumn{2}{|c|}{ Micronesia } \\
\hline wI & \multicolumn{2}{|r|}{244} & \multicolumn{2}{|c|}{$210-260$} \\
\hline$H^{\prime}$ & 5.26 & $(5.20-5.31)$ & 2.46 & $(0.95-3.30)$ \\
\hline$d^{\prime}$ & 0.96 & $(0.96-0.96)$ & 0.72 & $(0.29-0.87)$ \\
\hline$\alpha$ & 28.0 & $(26.2-30.0)$ & 3.4 & $(1.8-4.9)$ \\
\hline$s_{(100)}$ & 43.0 & $(41.5-44.4)$ & 11.7 & $(8.5-15.0)$ \\
\hline$b$ & 46.5 & $(44.4-48.6)$ & 7.4 & $(2.9-10.5)$ \\
\hline
\end{tabular}

Equatorial

South America

\begin{tabular}{|c|c|c|c|c|}
\hline \multirow[b]{2}{*}{ WI } & \multicolumn{2}{|c|}{ Amazonian upstreamt } & \multirow{2}{*}{\multicolumn{2}{|c|}{$\begin{array}{c}\text { Galápagos } \\
200-208\end{array}$}} \\
\hline & & & & \\
\hline$H^{\prime}$ & 4.65 & $(4.41-4.96)$ & 1.52 & $(0.40-2.37)$ \\
\hline$d^{\prime}$ & 0.95 & $(0.94-0.96)$ & 0.46 & $(0.11-0.70)$ \\
\hline$\alpha$ & 26.5 & $(22.6-42.6)$ & 2.1 & $(0.8-4.4)$ \\
\hline$S_{(100)}$ & 40.5 & $(37.2-42.6)$ & 7.8 & $(4.0-13.9)$ \\
\hline$b$ & 41.8 & $(36.1-45.0)$ & 7.9 & $(1.4-12.9)$ \\
\hline
\end{tabular}



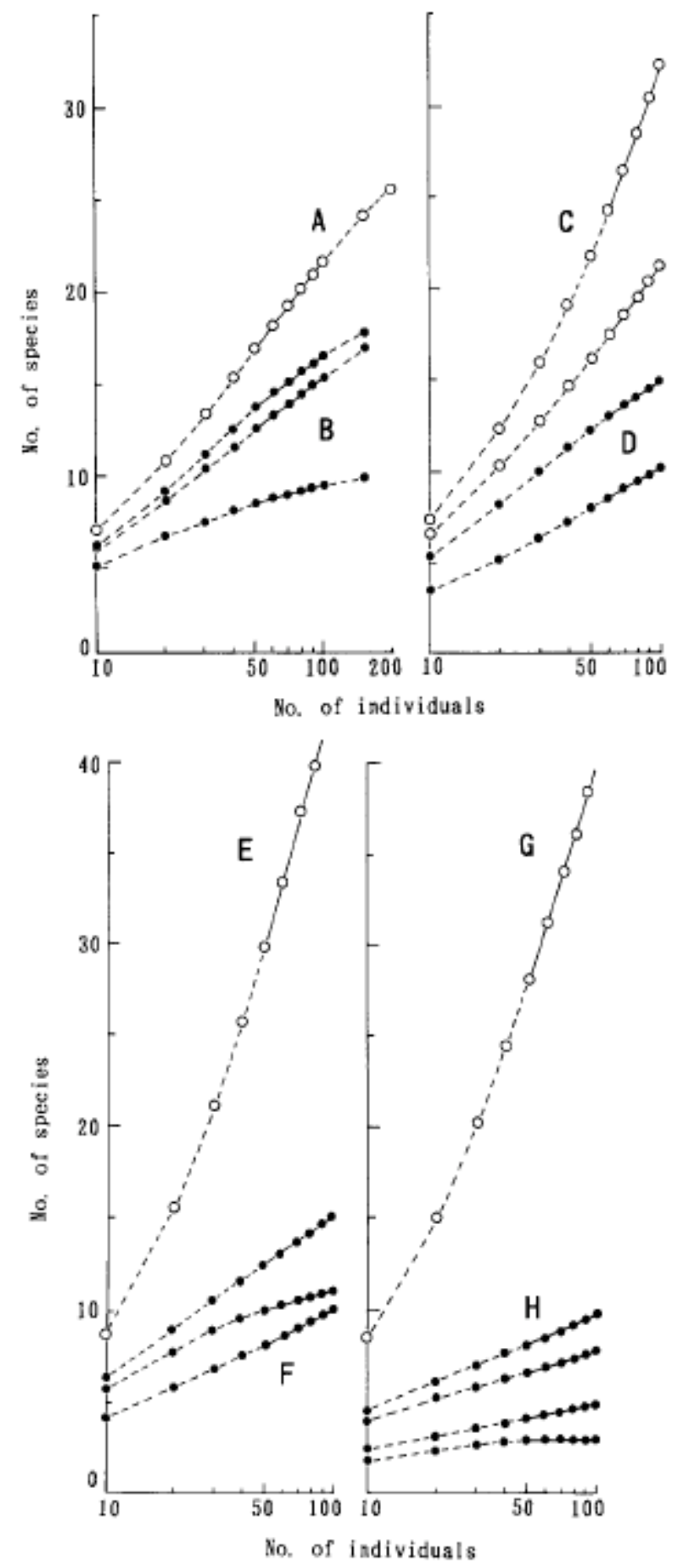

Fig. 3. S-N curves, comparing mainland (open circle) and insular (closed circle) communities, a. A-D: warmtemperate (A: Kyushu, B: Kyushu satellite islands) and subtropical climates (C: Ryukyu, D: Bonin); b. E-H: tropical climates (E: Thailand, F: Micronesia), and in equatorial South America (G: Amazon in Mainland Ecuador, H: Galapagos). The curves of the Thailand and Amazonian communities were based on calculations from Ogawa et al. (1965) and Grubb et al. (1963), respectively. 


\section{Acknowledgements}

I am grateful to Hendrik Hoeck and Friedman Koester, directors of Charles Darwin Research Station, Galapagos, who kindly arranged my stay in the Station and field work on Isla Santa Cruz in 1978 and 1981, respectively.

\section{References}

Auclair, A. N. \& Goff, E G. 1971. Diversity relations of upland forests in the western Great Lakes area. Amer. Nat. 105: 499- 528.

Bailey, K. 1976. Potassium-Argon ages from the Galapagos Islands. Science 192: 465-467.

Cottam, G. \& Curtis, J. T. 1956. The use of distance measurements in phytosociological sampling. Ecology 37: 451-460.

Glenn-Lewin, D. C. 1977. Species diversity in North American temperate forests. Vegetatio 33: 153-162. Grubb, P. J., Lloyd, J. R., Pennington, T. D. \& Whitmore, T. C. 1963. A comparison of montane and lowland rain forest in Ecuador. I. The forest structure, physiognomy, and floristics. J. Ecol. 51: 567-601. Hamann, O. 1979. On climatic conditions, vegetation types and leaf size in the Galapagos Islands. Biotropica 11: 101-122.

Hurlbert, S. H. 1971. The nonconcept of species diversity: A critique and alternative parameters. Ecology 52: 577-586.

Itow, S. 1971. A study of vegetation in Isla Santa Cruz, Galapagos Islands. Not. Galapagos 17: 10-13. Itow, S. 1984. Species diversity of Fagaceae-absent evergreen broadleaf forests on three NW-Kyushu satellite islands. Jap. J. Ecol. 34: 225-228.

Itow, S. 1985. Species diversity-climate-isolation relationships in warm-temperate and subtropical evergreen broadleaved forests on Kyushu, the Ryukyus and the Bonins. In: Hara, H. (ed.), Origin and evolution of diversity in plants and plant communities. Academia, Tokyo.

Itow, S. 1986. Species diversity of equatorial insular forests on Ponape and Kosrae, Micronesia. Ecol. Res. 1: 223-227.

Itow, S. \& Miyata, I. 1977. Species diversity of plant communities. In: Itow, S. (ed.), Species composition and structure of plant communities. Asakura, Tokyo. (In Japanese).

Itow, S., Ono, M. \& Seki, T. 1984. Species diversity of sub-tropical evergreen broadleaf forests on the Ryukyu and the Bonin Islands. Jap. J. Ecol. 34: 467-472.

Kanehira, R. 1972. Flora Micronesica. Inoue-Shoten, Tokyo.

Kira, T. 1977. A climatological interpretation of Japanese vegetation zones. In: Miyawaki, A. \& Tuexen, R. (ed.), Vegetation science and environmental protection. Maruzen, Tokyo. Lawesson, J. E. 1988. The stand-level dieback and regeneration of forests in the Galapagos islands. Vegetatio. 
Miyawaki, A. \& Sasaki, Y. 1985. Floristic changes in the Castanopsis cuspidata var. sieboldii-forest communities along the Pacific Ocean coast of the Japanese Islands. Vegetatio 59: 225 - 234.

Nakano, K., Itow, S., Une, S. \& Cornelius, G. 1986. Overview of habitat-types and horticultural land-use in Kosrae, Pohnpei and Truk Islands. Prompt Report of 4th Sci. Survey, South Pacific, 1-7. Kagoshima Univ., Kagoshima.

Ogawa, H. et al. 1965. Comparative ecological study on three main types of forest vegetation in Thailand. I. Structure and floristic composition. Nature and Life in SE Asia 4: 13-48.

Okutomi, K. et al. 1985. Vegetation of the Bonin Islands. In: Ono, M. \& Okutomi, K. (eds), Endemic plants and vegetation of the Bonin Islands. Aboc-sha, Kamakura. (Japanese with English summary.)

Ono, M. \& Sugawara, T. 1981. An analysis of the flowering plant flora of the Ogasawara (Bonin) Islands with their mode of dispersal. Ogasawara Res. 5: 25-40.

Peer, R. K. 1978. Forest vegetation of the Colorado front range: Patterns of species diversity. Vegetatio 37: 65-78.

Peet, R. K., Glenn-Lewin, D. C. \& Walker Wolf, J. 1983. Prediction of man's impact on plant species diversity - A challenge for vegetation science. In: Holzner, W., Werger, M. J. A. \& Ikushima, I. (eds), Man's impact on vegetation, pp. 41-54. Dr W. Junk, Dordrecht.

Shimizu, Y. 1983. Phenological studies of the subtropical broadleaved evergreen forests at Chichijima Island in the Bonin (Ogasawara) Islands. Jap. J. Ecol. 33: 135-147.

Whittaker, R. H. 1972. Evolution and measurement of species diversity. Taxon 21: 213-251.

Whittaker, R. H. 1977. Evolution of species diversity in land communities. Evol. Biol. 10: 1-67.

Wiggins, I. L. \& Porter, D. M. 1971. Flora of the Galapagos Islands. Stanford Univ. Press, Palo Alto.

Williams, C. B. 1947. The logarithmic series and its application to biological problems. J. Ecol. 34: 253-

272. 